\title{
Non-Academic Achievement Improvement Through Extracurricular
}

\author{
Aulia Diana Devi ${ }^{1}, \mathrm{Na}{ }^{\prime} \mathrm{imah}^{2}{ }^{2}$, Aqimi Dinana ${ }^{3}$ \\ 1,2,3 Universitas Islam Negeri Sunan Kalijaga Yogyakarta \\ email: ${ }^{1}$ 19204090026@ student.uin-suka.ac.id, ${ }^{2}$ drnaimah24@ gmail.com, \\ 319204090024@student.uin-suka.ac.id
}

Received: 29 Januari 2021; Revised: 26 Februari 2021; Accepted: 28 April 2021

DOI: http://dx.doi.org/10.37905/aksara.7.2.283-292.2021

\begin{abstract}
Extracurricular activities are one of the containers in coaching and developing students' potential. This study aims to find out the management of extracurricular activities in improving the non-academic achievement of students in Madrasah Aliah Negeri 1 Tulang Bawang Barat. The method used is descriptive analysis using qualitative approach. This research conducts data collection techniques by observation, interviews, literature studies, and internet media. This study used primary data sources obtained through interviews and secondary data sources obtained through online media. The results showed that several steps in the management of extracurricular activities, such as planning, organizing, direction / implementation and evaluation as well as evaluation. Planning is carried out by investigating the number of extracurricular activities. Organizing is carried out by coordinating all components involved in the management of extracurricular activities. The implementation is carried out by arranging and arranging in writing so that the activities carried out can be directed and run smoothly in accordance with the guidelines. And the evaluation is done through member meetings and final assessments.
\end{abstract}

Keywords: Management, Extracurricular, Achievements.

\section{INTRODUCTION}

The functions and objectives of national education listed in Law No.20 of 2003 Article 3 on the National Education System is to serve to educate the life of the nation with the development and formation of dignified character and civilization of the nation, the main goal is to increase the potential of learners to be formed into human beings who believe and fear the existence of God Almighty, have a noble, physical and spiritually healthy morals, have knowledge, creative, capable, independent, and become a responsible and democratic citizen (Mulkati 2018, 62).

Based on the above law, in realizing the national education system is in dire need of cooperation between madrasah families and even the environment. An educational goal can be achieved in addition to formal education, it can also be achieved through nonformal education or commonly referred to as extracurricular activities (Saputro, Sukidin, dan Ani 2017, 49). Today the development of extracurricular activities is an important part of self-development in an educational institution (Adyanto, Muhajir, dan Fajriyah 2018, 49). Out there there are many madrasas that are known by the community through achievements in the academic field. However, many madrasahs are also known by the community through non-academic achievements as well as one of the 
achievements of extracurricular activities (Rizky Prayuda Putra 2020, 49). So this is what attracts attention for the community to choose this madrasah.

The development of students in Madrasah, should be symbolized through various containers or programs that are realized with the aim to support the educational process which then on its own initiative can improve skills, skills towards more advanced knowledge. There are many student coaching containers in Madrasah, one of which is extracurricular activities (Nurdiana dan Prayoga 2018, 10). Madrasah strives to realize, develop and nurture the talents of students in Madrasah through extracurricular activities (Kompri 2015, 225-226.).

With extracurricular management, an extracurricular activity will be able to be carried out in accordance with the expected objectives (Zakiyah dan Munawaroh 2018, 43). Management functions in general which include planning, implementation, and evaluation are applied in the management of extracurricular management functions (Astafiyah 2018, 268).

Extracurricular activities are an activity in which there is a gathering place for students tailored to various interests and talents and tendencies of learners in order to channel creativity and activities carried out outside the learning program (Astafiyah 2018, 264). Craft in his journal quotes Reynolds as stating that extracurricular activities can improve students' lives, and can also give students additional skills that they acquire and will be useful for the rest of their lives (Craft, t.t., 22.).

This extracurricular activity has a purpose in the development of talents and interests of students of interest, such as interests and talents in the fields of sports, arts, skills, scouting, and so forth (Syafaruddin 2005, 265.). Therefore, in order to realize good extracurricular activities, a management is needed to regulate all the processes of extracurricular activities.

An extracurricular activity can be said to be successful if in the development of talents and interests owned by the learners can develop well and be able to have extensive knowledge and insight so that later can support the extracurricular activities that exist madrasah (Saputro, Sukidin, dan Ani 2017, 50.). Similarly, an extracurricular activity will not be successful if the management is not done well by madrasah (Indah Nur Aini Putri $2020,118)$. This reinforces the reason that the effectiveness of the management of extracurricular activities becomes very important because the success that will be achieved not only in the implementation of its activities but also supports the success of education in extracurricular activities. Educational objectives designed to be achieved to the maximum if the management of education is carried out with good management, including extracurricular activities (Jamaluddin, t.t., 169.).

MAN 1 Tulang Bawang Barat is a madrasah in Islamic educational institutions that in improving its quality one of them with improved achievements in madrasah. This madrasah is one of the MAN located in Tulang Bawang Barat district where this madrasah makes extracurricular activities become a characteristic of madrasah in obtaining various achievements.

In improving the achievements of learners MAN 1 Tulang Bawang Barat is in need of strong support in a learning activity. Of course, it is also in dire need of adequate educational facilities and infrastructure in accordance with the National Standards of Education (SNP). MAN 1 Tulang Bawang Barat is also an institution that has a very big commitment. All members of the stake holder in MAN 1 Tulang Bawang Barat also 
participated in helping realize the vision and mission of MAN 1 Tulang Bawang Barat. In seeking to develop the interests and talents of learners, MAN 1 Tulang Bawang Barat is characterized by providing a very diverse container of extracurricular activities.

The previous research conducted by Qiqi Yuliati Zakiyah and Ipit Saripatul Munawaroh, with the title of research "Extracurricular Management madrasah MAN Model Cipasung". The results of his research showed that extracurricular design is carried out at the beginning of each learning year, students are conditioned to follow the activities in the implementation of extracurricular, after the activities are carried out evaluation in order to get input improvement or development in policy decision making in the future (Zakiyah dan Munawaroh 2018).

Based on the previous research above, it can be concluded that there are similarities with this study, namely both conducting research on extracurricular activities. However, this study will not only focus on the process of extracurricular management, but will also examine how the management of these extracurricular activities in the non-academic achievement of students in MAN 1 Tulang Bawang Barat. MAN 1 Tulang Bawang Barat has quite a lot of extracurricular activities, therefore researchers make this madrasah as a research site that has the implementation of extracurricular activities that make students have many achievements from various branches of competition in the field of nonacademic.

\section{LITERATURE RIVIEW \\ Non Academic Achievement}

Mulyasa said that the results of activities carried out, carried out and so on can be said as achievements. If the planned activities are not carried out, then achievements will not be achieved. Mulyasa's opinion can be concluded that one can achieve achievements if one has efforts in carrying out activities, this is the highest point in the development of self-potential (Mulyasa, E. 2015, 25.). Then the UPI Education Administration Lecturer Team explained that the extracurricular activities referred to in educational institutions are non-academic activities. Then non-academic achievement can be called extracurricular achievement. Extracurricular activities are activities outside the compulsory school subject matter (Tim Dosen Administrasi Pendidikan Uiversitas Pendidikan Indonesia 2012, 212.).

\section{Extracurricular}

In modern times today, the urgency of extracurricular activity programs undergoes a series of evolutions. Robert Freeman cites Gholson who identified three periods in the process of developing extracurricular activities (Freeman, t.t., 15.) :

1. Phase 1 (1870-1890) was labeled as a rejection period. Education leaders concluded that few, if any, students would benefit from it expanding human or material resources, which they label extracurricular.

2. Phase 2 (1900-1920) was the period of passive acceptance. The leader concluded that student clubs and organizations are able to provide learning experiences for young people.

3. Phase 3 (1920-1956) was a period of active acceptance and encouragement. Debate on the educational benefits of participation in student activities is resolved for the sake of student involvement. 
Regulation of the Minister of Education and Culture of the Republic of Indonesia No. 81A of 2013 has an extracurricular definition of various educational activities carried out by students at times outside the standard curriculum lesson hours as a form of curriculum activity development and implemented with school guidance. Extracurricular activities have the purpose of developing the personality, interests, talents, and abilities of learners to be wider or outside the interest hours developed by the curriculum (Peraturan Menteri Pendidikan dan Kebudayaan Republik Indonesia Nomor 81A tahun (2013), t.t.). In the Regulation of the Minister of Education and Culture of the Republic of Indonesia Number 81A of 2013 concerning the Implementation of Curricular Guidelines for Extracurricular Activities governing: Extracurricular Activities are educational activities carried out by students outside the standard of curriculum learning time, namely the expansion of curriculum activities carried out in Madrasah. The goal is to foster the personality, talents, interests and abilities of learners who have learning abilities more or more than curriculum development capabilities (Permendikbud 2003). The term extracurricular refers to other activities outside of curriculum planning or other education outside the curriculum. According to Farida Yusuf quoted by Suryosubroto: "Extracurricular learning activities are carried out outside of basic school hours" (Suryosubroto 2002, 271).

Bartkus et al (2012) define extracurricular activities as "academic or non-academic activities conducted under the auspices of the school but occur outside of classroom time customs and are not part of the curriculum." Bartkus et al. (2012) also stated that "extracurricular activities do not involve grades or academic credit and participation is an option that exists in students" (Bartkus dkk. 2012). Conclusions that can be drawn from some opinions expressed that extracurricular activities are a learning activity conducted outside regular class hours designed to develop subjects based on the potential, talents and interests of students. According to Suryosubroto: "Extracurriculars are designed to develop a set of subject areas of interest to students, such as sports, art, various skills, and scouting" (Suryosubroto 2002, 271). Rusman believes that the main purpose of extracurricular activities is to "make room for students in the form of experiences that suit the interests, hobbies of talents and abilities that students have" (Rusman 2011, 20). Participation in school-based extracurricular activities such as sports, arts, and academic clubs, provides opportunities for student development both educationally and mentally (Mahoney, Harris, dan Eccles 2006, 3.). There have been many studies that have shown a positive relationship between participating in after-school sports or organizational activities and student final Average Grades. Abruzzo et al. quoted Mahoney et al. as stating that adolescent activity participation has been found to be associated with higher educational attainment, and achievements reduce problematic behaviors and high psychosocial competencies (Abruzzo dkk. 2016, 21.).

The implementation of extracurricular activities in Madrasah to carry out coaching not only brings many benefits for students, but also brings many benefits for educational efficiency in Madrasah. Extracurricular activities have a variety of functions and meanings in supporting the realization of the main purpose of education. This will be achieved if the management of extracurricular activities is carried out to the maximum extent possible, especially student management, and the discipline of students and all personnel is improved. Usually, managing students in their free time is more difficult when compared to managing students in the classroom. 


\section{RESEARCH METHODS}

This study uses qualitative descriptive research methods. With data collection techniques in the form of observations, interviews, literature studies, and internet media. The data in this study uses primary data sources obtained through interviews and secondary data sources obtained through online media. Data analysis is done by using several steps including data collection, data reduction, data display, and conclusion drawing. The informant in the study was the principal. For the research site was conducted at MAN 1 Tulang Bawang Barat which is located at Jalan Merdeka No. 1 RT 05 RW 03, Mulya Kencana, Tulang Bawang Tengah District, Tulang Bawang Barat Regency, Lampung Province. This research has the purpose of knowing extracurricular activities in improving non-academic achievement of students in MAN 1 Tulang Bawang Barat. The reason researchers make this Madrasah as a research location is because this Madrasah has several extracurricular programs that are considered to have many achievements obtained both in the academic and non-academic fields.

\section{RESULTS AND DISCUSSION Results}

Extracurricular activities are a place for students to actualize themselves that sometimes can not be found in formal teaching and learning activities, both in the field of sports, leadership, religion, and the arts (Ubaidah, t.t., 158). Madrasah can benefit from the development of extracurricular activities, namely as a means of socialization and promotion of Madrasah to the wider community, especially the community around the Madrasah environment. The trust and quality of Madrasah can be increased in the view of the community with the achievements achieved by Madrasah. Activities organized in extracurricular programs based on objectives designed in madrasah curriculum (Nurdiana dan Prayoga 2018, 10). Students are encouraged to have achievements outside the academic field with a variety of extracurricular activities. Students' achievements in nonacademic fields can be obtained through extracurricular activities that develop their interests, talents, and creativity.

MAN 1 Tulang Bawang Barat has 32 extracurricular both academic and nonacademic which are listed in the following table:

Table 1.Extracurricular Activities of MAN 1 Tulang Bawang Barat

\begin{tabular}{|c|c|}
\hline \multicolumn{2}{|c|}{ MAN 1 TBB Extracurricular Activities } \\
\hline Academic & Non Academic \\
\hline $\begin{array}{ll}\text { 1. } & \text { Computer } \\
\text { 2. } & \text { Arabic club } \\
\text { 3. } & \text { English club } \\
\text { 4. Art } \\
\text { 5. } \\
\text { 6. Cahfidz Al-Qur'an } \\
\text { 7. Journalism } \\
\text { 8. Ilmiyah's writings }\end{array}$ & $\begin{array}{l}\text { 1. Sports: table tennis, badminton, basketball, volly ball, } \\
\text { football, futsal, athletics, Pencak silat. } \\
\text { 2. Pramuka. } \\
\text { 3. Arts and culture. Among them: dance, dramatic, and } \\
\text { music. } \\
\text { 4. KIR } \\
\text { 5. UKS } \\
\text { 6. PMR } \\
\text { 7. OSIS } \\
\text { 8. Paskibra } \\
\text { 9. Skills } \\
\text { 10. MTQ } \\
\text { 11. Syarhil Qur'an } \\
\text { 12. Dai/daiyah } \\
\text { 13. Sewing (tata boga) } \\
\text { 14. Electronics }\end{array}$ \\
\hline
\end{tabular}


MAN 1 Tulang Bawang Barat is one of the MAN located in Tiyuh Mulya Kencana District Tulang Bawang Tengah Tulang Bawang Regency West Lampung Province. Based on the results of the interview, MAN 1 Tulang Bawang Barat has achieved quite a lot. MAN 1 Tulang Bawang Barat has achieved quite a lot of akdemic and non-akdemic achievements both at the sub-district, district, city, and provincial levels. Below is a list of achievements obtained:

Table 2. MAN 1 Tulang Bawang Barat Achievement List

\begin{tabular}{|c|c|c|c|}
\hline No. & Name & Description & Years \\
\hline 1. & David Qomarifa'i & $\begin{array}{c}\text { Pramuka National Scouts (Asian Scout Jambore } \\
\text { Thailand) }\end{array}$ & 2019 \\
\hline 2. & Mustakim Hidayat & Paskib District Level & 2019 \\
\hline 3. & Saputri & Paskib District Level & 2019 \\
\hline 4. & Muhammad Nur Safik & 3rd Winner of Provincial Athletics Championship & 2019 \\
\hline 5. & Pensi 3rd Place & $\begin{array}{c}\text { Saka Bayang Kara Branch Level } 2 \text { Tulang Bawang } \\
\text { Barat }\end{array}$ & 2019 \\
\hline 6. & $\begin{array}{l}\text { Neatness Of TentsThe } \\
\text { Champion of Hope }\end{array}$ & $\begin{array}{c}\text { Saka Bayang Kara Branch Level } 2 \text { Tulang Bawang } \\
\text { Barat }\end{array}$ & 2019 \\
\hline 7. & $\begin{array}{l}\text { Semapur Putra 3rd } \\
\text { Place 3rd Place }\end{array}$ & GPTP level 5 Kwarcab & 2019 \\
\hline 8. & Faisal Ega Pratama & $\begin{array}{c}\text { 3rd Winner of Integrated Physics KSM District } \\
\text { Level }\end{array}$ & 2019 \\
\hline 9. & $\begin{array}{l}\text { Elsa Rosdinana } \\
\text { Harahap }\end{array}$ & $\begin{array}{c}\text { 3rd Winner of Integrated Geography of KSM } \\
\text { District Level }\end{array}$ & 2019 \\
\hline 10. & Nur Fadilah Harahap & 2nd Winner of Economy & 2019 \\
\hline 11. & $\begin{array}{l}\text { Volly Women's 1st } \\
\text { Place }\end{array}$ & District Scope Madrasah Level & 2020 \\
\hline 12. & Volly Men's 2nd Place & District Scope Madrasah Level & 2020 \\
\hline 13. & Futsal 2nd Place & District Scope Madrasah Level & 2020 \\
\hline 14. & $\begin{array}{l}\text { Badminton Women's } \\
\text { Champion } 2\end{array}$ & District Scope Madrasah Level & 2020 \\
\hline 15. & $\begin{array}{l}\text { Athletics } 100 \text { meters } \\
\text { winners } 1 \text { st, } 2 \text { nd and } \\
\text { 3rd }\end{array}$ & District Scope Madrasah Level & 2020 \\
\hline 16. & $\begin{array}{l}\text { Men's Table Tennis } \\
\text { Champion } 2\end{array}$ & District Scope Madrasah Level & 2020 \\
\hline 17. & $\begin{array}{l}\text { Table Tennis Women's } \\
\text { Champion } 2\end{array}$ & District Scope Madrasah Level & 2020 \\
\hline 18. & $\begin{array}{l}\text { Maharani Putri } \\
\text { Azzahra }\end{array}$ & $\begin{array}{l}\text { Champion of Hope Dai Muda Kanwil Kemenag } \\
\text { Lampung Province }\end{array}$ & 2020 \\
\hline
\end{tabular}

Mr. H. Imam Kahfi as Head of MAN 1 Tulang Bawang Barat, revealed that efforts and steps in achieving and maintaining these non-academic achievements are by applying the management of extracurricular activities inMadrasah. That is, as every beginning of the period MAN 1 Tulang Bawang Barat make a work program planning and always monitored its development, as well as conduct evaluations and assessments which are done at the end of each school year.

But in his application, he also revealed that there are still many obstacles faced in the management of these extracurricular activities. As with the many extracurriculars that exist and the long time of curricular lesson hours, it is often difficult to manage the time and schedule of extracurricular activities. Then other obstacles also such as the lack of 
funds owned madrasah in financing extracurricular activities which can affect for the provision of facilities, competition activities and others, of course requires a lot of costs, from problems and obstacles that there are many potentials, talents, and abilities of students that are not channeled well.

\section{Discussion}

With the increasing non-academic achievements and the development of extracurricular activities in Madrasah, it is necessary to take a good coaching action, one of which is by carrying out management in extracurricular activities so that the activity can really benefit the students and madrasah itself. Siti Fatimah argues that the term management in Islamic view comes from the word yudabbiru, which has the meaning of managing, directing, running, implementing, managing, and organizing. Yudabbiru is derived from the word dabbara which has the meaning of regulating and mudabbir which has the meaning of a person who has the cleverness to regulate or regulate and mudabbar which has the meaning of regulated (Siti Fatimah 2015, 1.).

Mulyono expressed his opinion that extracurricular management is a thorough process that has been designed and attempted in an organized manner related to madrasah activities carried out after lesson hours in order to develop the potential owned by students, both concerning knowledge and related to self-potential achieved through various mandatory activities and choices (Zakiyah dan Munawaroh 2018, 43). Based on this, MAN 1 Tulang Bawang Barat itself has taken several steps in carrying out the management of extracurricular activities. Beginning with planning, organizing, direction / implementation and evaluation as well as evaluation.

In the process of designing extracurricular activities in MAN 1 Tulang Bawang Barat conducted with an inventory of the number of extracurricular activities, all new students fill out the form at the time of PPDB to know the interests and talents owned by new students. In addition, madrasah also provides academic achievement pathways and non-academic achievements, designing extracurricular activity program plans for a period of one year such as: the preparation of training activity schedules for students and the preparation of extracurricular activities in Madrasah.

Madrasah conducts organizing by coordinating with all elements involved in the management of extracurricular activities, division of duties and obligations to all elements who participate in managing or handling extracurricular activities, and appointing delegates as responsible for the implementation of extracurricular activities. The whole process of organizing madrasah has been running optimally. The whole series of planning to implementation can run smoothly of course thanks to the help of all parties who participated in the activities in accordance with the field that is steamed by each element, ranging from the Head of Madrasah, Deputy Head of Madrasah student section, coaches or coaches of extracurricular activities and students who participated in the extracurricular activities.

Then, for the process of briefing or implementation of extracurricular activities, MAN 1 Tulang Bawang Barat organizes and compiles implementation guidelines in writing so that the extracurricular activities carried out are directed and run smoothly in accordance with the guidelines that have been designed. At the beginning of the new school year, the direction or implementation of extracurricular activities begins. Madrasah has first compiled a series of schedules of extracurricular activities. The 
implementation of extracurricular activities is carried out after madrasah intracuriular lesson hours, this is so that students are not disturbed while the lesson hours are still taking place. In the direction and implementation of extracurriculars, it has been carefully prepared from afar to see every development and preparation of pesrta didik. From the beginning of the selection process, initial coaching, material delivery, preparation of works, consultation, and collection of works.

And the latter is the process of evaluating extracurricular activities that are very necessary to do. The madrasah conducts an evaluation process with the aim that the madrasah has a benchmark whether the implementation of extracurricular activities has been carried out in accordance with the prevailing designs and rules and no irregularities. If there are irregularities that occur in extracurricular activities, then improvements aimed at improving and developing extracurricular activities can be carried out in extracurricular activities in the future. In the extracurricular evaluation of MAN 1 Tulang Bawang Barat, futsal for example the implementation is constrained by several things, among others, the trainer is not from the alumni of the school, then the facilities are not adequate, as well as the target for futsal cheese is minimal. So the school must make extra efforts in this futsal extracurricular.

\section{CONCLUSION}

Based on the results and discussions that have been carried out, it can be concluded that extracurricular activities are an activity in which there is a forum for students association tailored to various interests and talents and tendencies of learners in order to channel creativity and activities carried out outside the program of learning activities. MAN 1 Tulang Bawang Barat has several steps in the management of extracurricular activities, such as planning, organizing, briefing or implementation and evaluation as well as evaluation. In the process of designing extracurricular activities, MAN 1 Tulang Bawang Barat inventoryed the number of extracurricular activities, all new students filled out the form at the time of PPDB to find out the interests and talents owned by the new students. The organizing process is carried out by coordinating all elements involved in the management of extracurricular activities. In the implementation process, all extracurricular activities are arranged and arranged in writing so that the activities carried out can be directed and run smoothly in accordance with the guidelines, briefings or implementation of extracurricular activities starting from the beginning of the school year. And the latter at the evaluation stage has been implemented properly and on target by conducting a member meeting and final assessment.

\section{REFERENCE}

Abruzzo, Kristen J., Cristina Lenis, Yansi V. Romero, Kevin J. Maser, dan Elsa-Sofia Morote. 2016. "Does Participation in Extracurricular Activities Impact Student Achievement?" Journal for Leadership and Instruction 15 (1): 21-26.

Adyanto, Sisworo Putut, Muhajir Muhajir, dan Khusnul Fajriyah. 2018. "Karakteristik Siswa Anggota Ekstrakulikuler Pencak Silat Ditinjau Dari Nilai Karakter.” Jurnal Sinektik 1 (1): 46-52. 
Astafiyah, Astafiyah. 2018. "Kontribusi Efektivitas Manajemen Ekstrakurikuler Terhadap Prestasi Sekolah Non Akademik." Tarbawi: Jurnal Keilmuan Manajemen Pendidikan 4 (02): 263-74.

Bartkus, Kenneth R., Blake Nemelka, Mark Nemelka, dan Phil Gardner. 2012. "Clarifying The Meaning Of Extracurricular Activity: A Literature Review Of Definitions." American Journal of Business Education (AJBE) 5 (6): 693-704.

Craft, Steven Wesley. t.t. "The Impact of Extracurricular Activities on Student Achievement at the High School Level," 94.

Freeman, Robert. t.t. "The Relationship Between Extracurricular Activities And Academic Achievement," 107.

Indah Nur Aini Putri, Heru Santoso. 2020. "Manajemen Kegiatan Ekstrakulikuler Robotik Di SMA Negeri 28 Jakarta." Jurnal Improvement 7 (1).

Jamaluddin. t.t. "Manajemen Ekstrakulilkuler Madrasah Aliyah." JIEM (Journal of Islamic Education Manajemen) Vol. 3 (2).

Kompri. 2015. Manajemen Pendidikan. Yogyakarta: Ar-Ruzz Media.

Mahoney, Joseph L., Angel L. Harris, dan Jacquelynne S. Eccles. 2006. "Organized Activity Participation, Positive Youth Development, and the Over-Scheduling Hypothesis." Social Policy Report 20 (4): 1-32.

Mulkati, Ujang. 2018. "Manajemen Ekstrakurikuler Keagamaan Di Man 2 Kota Bengkulu" 3 (1): 11.

Mulyasa, E. 2015. Menjadi Guru Profesional, Menciptakan Pembelajaran Kreatif dan Menyenangkan. Bandung: Remaja Rosdakarya.

Nurdiana, Mia, dan Ari Prayoga. 2018. "Fungsi-Fungsi Manajemen dalam Kegiatan Ekstrakurikuler Pramuka di Madrasah.” Madrasa: Journal of Islamic Educational Management 1 (Desember): 9-15.

Peraturan Menteri Pendidikan dan Kebudayaan Republik Indonesia Nomor 81A tahun (2013). t.t.

Permendikbud. 2003. Permendikbud, Nomor 81A Tahun 2003 tentang Implementasi Kurikulum Pedoman Kegiatan Ekstrakurikuler.

Rizky Prayuda Putra, Advendi Kristiyandaru. 2020. "Manajemen Ekstrakulikuler Olahraga Di SMP Dr. Soetomo Surabaya." Jurnal Pendidikan Olahraga dan Kesehatan 08 (02).

Rusman. 2011. Manajemen Kurikulum. Jakarta: Rajawali Press.

Saputro, Ruliyanto Ratno, S. Sukidin, dan Hety Mustika Ani. 2017. "Manajemen Ekstrakurikuler Non-Akademik Siswa Di SMA Muhammadiyah 3 Jember." Jurnal Edukasi 4 (3): 49-53.

Siti Fatimah. 2015. Manajemen Kepemimpinan Islam. Bandung: Alfabeta.

Suryosubroto. 2002. Proses Belajar Mengajar di Sekolah. Jakarta: Rineka Cipta.

Syafaruddin. 2005. Manajemen Lembaga Pendidikan Islam. Jakarta: Ciputat Press.

Tim Dosen Administrasi Pendidikan Uiversitas Pendidikan Indonesia. 2012. Manajemen Pendidikan. Bandung: Alfabeta.

Ubaidah, Siti. t.t. "Pembahasan Mutu Sekolah," 12.

Zakiyah, Qiqi Yuliati, dan Ipit Saripatul Munawaroh. 2018. "Manajemen Ekstrakurikuler Madrasah.” Jurnal Isema : Islamic Educational Management 3 (1). 
AKSARA: Jurnal Ilmu Pendidikan Nonformal

P-ISSN 2407-8018 E-ISSN 2721-7310DOI prefix 10.37905

Volume 07 (02) Mei 2021

http://ejurnal.pps.ung.ac.id/index.php/Aksara 